\title{
Article \\ Nephroprotective Effects of Alhagi camelorum against Cisplatin-Induced Nephrotoxicity in Albino Wistar Rats
}

\author{
Muhammad Omer Iqbal 1,2,*(D), Muhammad Masood Ahmed ${ }^{3,4}$, Shafia Arshad ${ }^{(\mathbb{D})}$, Usman Javaid ${ }^{6}$, \\ Imran Ahmad Khan 2,7,*D, Majid Manzoor ${ }^{3}$, Shumaila Andleeb ${ }^{8}$, Romana Riaz ${ }^{9}$, Shaukat Hussain Munawar 10,* \\ Zahid Manzoor ${ }^{10}$ and Asma Mumtaz ${ }^{9,11}$
}

Citation: Iqbal, M.O.; Ahmed, M.M.; Arshad, S.; Javaid, U.; Khan, I.A.;

Manzoor, M.; Andleeb, S.; Riaz, R.; Munawar, S.H.; Manzoor, Z.; et al. Nephroprotective Effects of Alhagi camelorum against Cisplatin-Induced Nephrotoxicity in Albino Wistar Rats. Molecules 2022, 27, 941. https:// doi.org/10.3390/molecules27030941 Academic Editors: Gianluca Paventi, Giuseppe Rotundo and Giacinto S. Germinara

Received: 1 December 2021

Accepted: 26 January 2022

Published: 29 January 2022

Publisher's Note: MDPI stays neutral with regard to jurisdictional claims in published maps and institutional affiliations.

Copyright: (C) 2022 by the authors. Licensee MDPI, Basel, Switzerland. This article is an open access article distributed under the terms and conditions of the Creative Commons Attribution (CC BY) license (https:// creativecommons.org/licenses/by/ $4.0 /)$.
1 Shandong Provincial Key Laboratory of Glycoscience and Glycoengineering, School of Medicine and Pharmacy, Ocean University of China, Qingdao 266003, China

2 Fatima Tu Zahara Department of Life Sciences, Muhammad Institute of Medical and Allied Sciences, Multan 60000, Pakistan

3 College of Pharmaceutical Sciences, Zhejiang University, Hangzhou 310058, China; masoodkarni@yahoo.com (M.M.A.); dr.majidmanzoor@yahoo.com (M.M.)

4 Faculty of Pharmaceutical Sciences, Times Institute Multan, Multan 60000, Pakistan

5 Faculty of Medicine and Allied Health Sciences, The Islamia University of Bahawalpur, Bahawalpur 93100, Pakistan; shafia.arshad@iub.edu.pk

6 Department of Pharmacology, Faculty of Pharmacy, Bahauddin Zakariya University, Multan 60800, Pakistan; usmanjavaidkhan1@gmail.com

7 Department of Pharmacology, The Islamia University of Bahawalpur, Bahawalpur 63100, Pakistan

8 Southern Punjab Institute of Health Sciences, Multan 60800, Pakistan; drshama2010@live.com

9 Department of Pharmaceutics, Faculty of Pharmacy, Bahauddin Zakariya University, Multan 60800, Pakistan; rummanariaz@yahoo.com (R.R.); asmahashmi83@gmail.com (A.M.)

10 Department of Pharmacology and Toxicology, Cholistan University of Veterinary and Animal Sciences, Bahawalpur 63100, Pakistan; zahidmanzoor@cuvas.edu.pk

11 Multan Medical and Dental College, Multan 60000, Pakistan

* Correspondence: oiqbal133@gmail.com (M.O.I.); imranahmadkhandurrani@gmail.com (I.A.K.); shaukathussainmunawar@cuvas.edu.pk (S.H.M.)

Abstract: Alhagi camelorum (AC) is an old plant with a significant therapeutic value throughout Africa, Asia, and Latin America. The overuse of cisplatin (Cis $>50 \mathrm{mg} / \mathrm{m}^{2}$ ) is associated with observed nephrotoxicity, ototoxicity, gastrotoxicity, myelosuppression, and allergic reactions. Remedial measures are needed for the protection of nephrotoxicity against cisplatin. Thus, we investigated the nephroprotective effects of AC plant extract to prevent cisplatin-induced nephrotoxicity in albino Wistar rats. The presence of polyphenols, phenolic compounds, tannins, and saponins was revealed during phytochemical investigation, and a significantly intense antioxidant activity was recorded. There were no toxicological symptoms in the treated rats, and no anatomical, physiological, or histological abnormalities were found compared to the control rats. The results of correcting cisplatin-induced nephrotoxicity revealed that the extract has a significant ability to treat kidney damage, with most parameters returning to normal after only three weeks of therapy. It is concluded that co-administration of cisplatin with AC extract showed exceptional nephroprotective effects at a dose of $600 \mathrm{mg} / \mathrm{kg}$ for Cis-induced nephrotoxicity.

Keywords: cisplatin; nephrotoxicity; reactive oxygen species; Alhagi camelorum

\section{Introduction}

According to emerging evidence, nephrotoxicity is one of the most persistent kidney problems with an $8-15 \%$ lifetime risk in Europe, $2-5 \%$ in Asia, and $20 \%$ in the Middle East [1]. Nephrotoxicity leads to a reduction in the glomerular filtration rate and an increase in creatinine and blood urea nitrogen in the serum, ultimately increasing the blood pressure and fluid retention in the body (over-hydration) [1,2]. Kidneys are the primary target organ to bear toxic effects of medication. Kidneys account for $25 \%$ of the heat 
output and are naturally exposed to circulatory drugs and chemicals as central excretion bodies. These nephrotoxic drugs contribute to acute kidney failure and increased morbidity and death $[3,4]$. Because of their functions in glomerular concentrations, drug delivery, and metabolism, the epithelial cells of the renal proximal convoluted tubules (PCT) are a crucial target for nephrotoxicants [5]. Nephrotoxic agents usually damage the renal tubular epithelial cells either by reacting indirectly (through metabolites) or directly with membrane components and cellular macromolecules [6,7].

Cisplatin (Cis) is the most commonly used potential chemotherapeutic agent against different solid tumors, including those in the head, neck, lung, breast, bladder, and ovary. Besides its multiple advantages, $C$ is is responsible for inducing several side effects, including ototoxicity, gastrotoxicity, myelosuppression, and allergic reactions [8,9]. According to emerging evidence, the main toxic effect of $\mathrm{Cis}$ is the dose-limiting nephrotoxicity that is responsible for mortality and morbidity $[10,11]$. Several previous studies indicated the nephrotoxicity of Cis at a single dose $\left(50-100 \mathrm{mg} / \mathrm{m}^{2}\right)$ [9,12]. Nephrotoxicity caused by Cis occurs mainly in renal PCT [13].

Nephrotoxicity is the most common adverse effect of Cis accumulation in kidneys after chemotherapy [14]. The Cis disturbs the equilibrium between antioxidants and peroxides, while renal fibrosis is closely related to a rise in oxidative damage [15,16]. The Cis-complex moves through the cell membranes in a unionized form due to its high chloride concentration in the plasma. Cl-plasma is higher than the intracellular concentration, and chloride ligands are displaced by water, resulting in a nephrotoxic formation of the positive platinum complexes. The Cis molecule binds to the guanine DNA base and inhibits DNA, RNA, and protein synthesis. Cis binds to the DNA interface, and an intrastrand is established, leading to a faulty genetic code model and the arrest of the formation and duplication of DNA replication $[17,18]$.

During the past few decades, natural compounds have been considered among the promising therapeutic agents against cancer, cardiovascular diseases, aging, diabetes, and especially neurodegenerative disorders due to their wide variety of modes of action, efficiency, accuracy, and fewer side effects $[19,20]$. Several studies have focused currently on traditional herbal medicines to evaluate novel therapeutic drugs for acute kidney injury (AKI) therapy. Various herbal medicines, including pomegranate (Lythraceae), Prosthechea michoacana (Orchidaceae), Zingiber officinale (Zingiberaceae), and red ginseng (family Araliaceae), have protective effects against cisplatin-induced acute kidney injury with vivo experiments [21-23].

Alhagi camelorum (AC) is a traditional herb that belongs to the family Leguminosae [24]. AC is used to treat metabolic, digestive, and hepatic problems, autoimmune diseases, headaches, and infections [25]. AC treats stomach problems of animals, heartworm, and pyrexia [21-23]. The herb is regarded as a laxative, diuretic, purgative, and antipyretic [26]. The major phytonutrients in AC include proteins, glycosides, coumarins, flavonoids, phenolics, resin, saponins, steroids, terpenes, ascorbic acid, essential oils, salicylic acid, ascorbic acid, and gallic acid [27]. This drove us to explore the nephroprotective effect of AC against chemotherapeutics such as cisplatin.

However, to the best of our knowledge, the in vivo toxicological effect and the nephroprotective effects of AC plant extract have not been identified. The current nephroprotective study serves as a necessary basis for further studies developing herbal medicine from this plant.

\section{Materials and Methods}

\subsection{Chemicals}

The analytical-grade chemicals included cisplatin (Mylan S.A.S, CHATILLON SUR CHALARONNE, AUVERGNE RHONE ALPES, France), 2, 2-Diphenyl, 1-picrylhydrazle, formalin, ketamine, and xylazine, which were purchased from Prix Lab Lahore, Pakistan. Ethanol (99.2\% pure), picric acid (99.5\% pure), $\mathrm{NaOH}$, and trichloroacetic acid (TCA; 97\% pure) were obtained from Sigma-Aldrich, St. Louis, MO, USA. The chemicals were 
mixed with other chemicals and with distilled water depended on the parameters and their protocols.

\subsection{Preparation of the Plant Extract}

AC was collected from the agricultural fields of Head Muhammad Wala, Multan, Pakistan. The plant was authenticated by expert taxonomists in the Department of Botany, Bahauddin Zakariya University, Multan, Pakistan, with the voucher number (R.R. Stewart F.W. Pak.711/12) for further reference. AC plants were washed, dried (under a shield), and powdered with the help of a herbal blender. AC powder $(1200 \mathrm{~g})$ was soaked in a hydroalcoholic solvent $(70: 30 \mathrm{v} / \mathrm{v})$ in an air-tight amber-colored bottle for nine days. A rotary evaporator (Heidolph Laborota 4000 efficient, Hamburg, Germany) was used to evaporate the filtrate at reduced pressure $[28,29]$. The obtained semi-solid residue was refrigerated before further analysis.

\subsection{Animals}

Albino Wistar male rats weighing 260-290 g were collected from the animal house of the Department of Life Sciences, Muhammad Institute of Medical and Allied Sciences, Multan, and kept in polycarbonate cages that were covered by raw dust that was changed every three days under standard laboratory conditions $\left(27 \pm 2{ }^{\circ} \mathrm{C}\right)$ in the Pharmacology Research Laboratory. The rats were given water and standard diet pellets ad libitum. All experiments performed were approved by the Animal Ethical Committee of the Muhammad Institute of Medical and Allied science, Multan, Pakistan [30], in accordance with the guidelines of the national research council [31].

\subsection{In Vivo Experiments}

A single dose of Cis $(5 \mathrm{mg} / \mathrm{kg})$ was injected into the rats to induce nephrotoxicity [32]. Rats were typically divided into four different groups of six animals each. Group-I was given normal saline by oral gavage for 21 days and used as a control. Group-II received Cis $5 \mathrm{mg} / \mathrm{kg}$ (i.p) on the first day and received saline for 21 days by oral gavage. Group-III was given Cis + AC extract $(400 \mathrm{mg} / \mathrm{kg}$; cisplatin was given on the first day and then the extract was given for 21 days by oral gavage), while Group-IV received Cis + AC extract $(600 \mathrm{mg} / \mathrm{kg}$; cisplatin was given on the first day and then the extract was given for 21 days by oral gavage). The plant extract was freshly suspended in distilled water before administration with the aid of Tween 80 . The rational choice of dose and treatment time was based on a previous study on different plants [30].

Daily food and water consumption was regularly measured with the body weights of the rats. The body weight was measured before the experiment, while kidney weight was measured by sacrificing the rats. The urine was collected on days 0,7 th, 14 th, and 21st from all experimental groups of rats by placing each rat on a plastic dish for sodium $(\mathrm{Na})$, potassium (K), and creatinine level analysis [33]. The rats were kept for $24 \mathrm{~h}$ in metabolic cages with tap water, and we measured the total intake of water and the amount of urine. The collected urine samples were stored at $-30{ }^{\circ} \mathrm{C}$ for the estimation of creatinine, $\mathrm{Na}$, and $\mathrm{K}$ levels. Similarly, the blood samples of all experimental groups were collected on days 0,7th, 14th, and 21st in EDTA tubes and centrifuged at $2300 \mathrm{rpm}$ to collect the plasma to estimate the creatinine, $\mathrm{Na}$, and $\mathrm{K}$ levels.

\subsection{Phytochemical Screening}

Phytochemical screening of the secondary metabolites and active compounds present in the AC extract was done using the standard protocols [34].

\subsection{HPLC Analysis}

The standard USP and ICH guidelines were carried out for the HPLC analysis to estimate phenolic acids and polyphenolic compounds [35]. The wavelength used for polyphenol identification was $280 \mathrm{~nm}$, while the temperature of the furnace column was 
adjusted to $35^{\circ} \mathrm{C}$. Ultimate 3000 liquid chromatography incorporating a $5 \mathrm{~cm}$ flow cell DAD and Chromeleon system management for HPLC analytics were used. The reversed-phase Acclaim C18 column (5-micron particle size, $250 \mathrm{~mm} / 4.6 \mathrm{~mm}$ ) was used to differentiate components. In total, $30 \mathrm{mg}$ dry methanol and water extract were dissolved separately in $25 \mathrm{~mm}$ of the mobile phase solvent. The $0.45 \mu \mathrm{m}$ membrane filter filtered the sample solution before injection (methanol: $0.5 \%$ acetate acid in water: 1.9 ) in the HPLC system. High-performance liquid chromatography analysis was conducted using the methanol phase containing the mobile solvent (Solvent A) and acetic acid solutions (Solvent B), with 105 min for each sample. The HPLC spectrum library recorded and stored each standard. With respect to the identification criteria for Alhagi camelorum, chemicals were determined when the retention time and spectrum of unknown compounds were compared to the HPLC standard library. In the extracts, phenolic acids and flavonoids were measured by applying the calibration graph by drawing spikes against the relevant standard control sample. The data are reported as the standard \pm error means for three independent assessments.

\subsection{Acute Oral Toxicity Dose Test}

The acute oral toxicity of AC was evaluated in 12 rats. Rats were divided into six groups; each group contained four rats. Rats were fasted for $24 \mathrm{~h}$ and dosed in the following manner: 500, 1000, 1500, 2000, 2500, $3000 \mathrm{mg} / \mathrm{kg}$ body weight. After the dosing, the rats were observed for 14 days for lethargy, jerkiness, and death [36].

\subsection{DPPH Assay}

To assess the antioxidant activity of the crude extract, photo-colorimetric methods were used to determine the free radical DPPH (2,2-Diphenyl-1-picrylhydrazyle) [37]. Samples of the ethanolic plant extract were diluted to 500, 1000, 1500, 2000, 2500, and $3000 \mathrm{ppm} ; 1 \mathrm{~mL}$ of each sample was added to the DPPH solution and prepared up to $5 \mathrm{~mL}$ with methanol, and then incubated for $40 \mathrm{~min}$. Mixtures were kept at $25^{\circ} \mathrm{C}$, and the measurements were carried out using a spectrophotometer at $517 \mathrm{~nm}$ (spectrophotometer UV-340 G, Gehaka Santa Clara, CA, USA), and ascorbic acid was used as a standard. The tests were performed three times for all samples, and the mean value was calculated.

\subsection{Biochemical Analyses}

Blood samples were screened to determine various biochemical parameters.

\subsection{Measurement of Plasma and Urine Sodium and Potassium Levels}

For the screening of electrolytes or an acid-base imbalance, the electrolyte profile was used to check the effects of any treatment. Electrolytes include sodium, potassium, chloride, and bicarbonates for the diagnosis of any condition or disease [38]. Sodium and potassium concentrations in plasma and urine were measured by using a flame photometer (Sherwood Model 410, Nottingham, UK).

The samples were diluted (1:200) for the measurement of sodium in urine and plasma samples, and for the measurement of potassium in plasma samples, the same dilution was used, but for the potassium levels in urine, the dilution was 1:1000. All samples were measured in triplicate.

\subsection{Urine Flow Rate}

The urine flow rate is the amount of urine excreted per unit time and it was calculated using the following formula in $\mu \mathrm{L} / \mathrm{min} / 100 \mathrm{~g}$ of $\mathrm{BW}$ :

$$
\text { Urine output }(\mathrm{mL} / 24 \mathrm{~h}) \times 1000 \times 100
$$

Urine flow rate $(\mu \mathrm{L} / \mathrm{min} / 100 \mathrm{~g}$ of $\mathrm{BW})=1440 \times \mathrm{Wt}$. of animal (grams) 


\subsection{Measurement of Plasma and Urine Creatinine Levels}

Creatinine is a catabolic product of creatine phosphate in muscles, and depending upon the muscle mass, it is usually produced at a fairly constant rate in the body [39].

Plasma and urinary creatinine concentrations were measured spectrophotometrically (Jaffe's reaction) by a method described before [40].

Urinary samples were diluted up to 50 times with distilled water. Both plasma and urine samples were deproteinized using trichloroacetic acid (1.2 M/L) along with centrifugation, and the supernatant was used for the measurement. The principle of this assay is based on the reaction between creatinine in the sample and picric acid in an alkaline medium to form a colored complex. This complex can be detected by a spectrophotometer at $520 \mathrm{~nm}$ wavelength. The complex formation should be measured in a short period after preparation to avoid interference. The preparation of the assay component is shown below in the table. The total volume of the sample, blank, and standard was transferred to a 96-well microtiter plate and incubated for 20 min at room temperature. Following the incubation period, the absorbance of the mixture was measured using a microplate reader (Synergy HT BioTek ${ }^{\circledR}$ Pittsburgh, PA, USA). All samples were analyzed in duplicate, and the concentration of creatinine in plasma and urine was calculated using the following formula:

Abs. of sample-Abs. of blank $\times$ Conc. of standard

Plasma conc. $(\mathrm{mg} / \mathrm{dL})=$ Abs. of standard - Abs. of blank

Abs. of sample-Abs. of blank $\times$ Conc. of standard $\times 50$

Urine conc. $(\mathrm{mg} / \mathrm{dL})=$ Abs. of standard-Abs. of blank

Abs $=$ Absorbance

\subsection{Histopathological Analysis}

The histopathological analysis of the kidney was performed using Olympus light microscopy $(\times 400)$ with an Olympus digital camera. Kidneys preserved in formalin were dehydrated, cleared in xylene, and placed in paraffin, and the kidney was cut into $5 \mu \mathrm{m}$ sections and stained with periodic acid Schiff and hematoxylin. First, specific sections ( $5 \mu \mathrm{m}$ each) of the kidneys were rehydrated and desalinized with alcohol. Next, these sections were treated with a particular amount of endogenous peroxidases for $0.5 \mathrm{~h}$ at $37^{\circ} \mathrm{C}$ and were rinsed three times in phosphate buffer saline (PBS) at $\mathrm{pH}$ 7.00. After rinsing, the kidney sections were heated with $0.01 \mathrm{M}$ sodium citrate buffer at pH 6.00 for $25 \mathrm{~min}$ and incubated for $1 \mathrm{~h}$ with 1\% BSA. After incubation, the sections were condensed with hematoxylin, dehydrated with alcohol, and cleaned with xylene $[37,38]$.

\subsection{Statistical Analysis}

One-way analysis of variance (ANOVA) and Bonferroni's post hoc analysis were performed for all data (mean $\pm \operatorname{SEM}(n=5)$ ) to determine the methodological significance between different experimental groups. Statistically, significance was considered at $p<0.05$ [36].

\section{Results}

\subsection{Phytochemical Analysis and Antioxidant Activity}

The phytochemical examination of the ethanol plant extract showed that flavonoids, phenolic compounds, tannins, and saponins were present, whereas triterpenoids, steroids, and anthocyanins were not detercted. The results of different antioxidant assays showed that the concentration-dependent DPPH radical scavenging activity of the ethanol extract of $A$. camelorum was highest at $3000 \mathrm{mg} / \mathrm{mL}(96.07 \%)$, whereas the lowest $(26.07 \%)$ was measured at $500 \mu \mathrm{g} / \mathrm{mL}$. The highest percentage decrease was measured at $3000 \mu \mathrm{g} / \mathrm{mL}$ with respect to the power reduction of the plant ex- 
tract (108.9 percent). At a lower concentration of $500 \mu \mathrm{g} / \mathrm{mL}$, the lowest percentage reduction power (60.1 percent) was measured. The nitric oxide activity of A. camelorum showed that increasing concentrations of the extract markedly increased the nitric oxide scavenging. At $3000 \mu \mathrm{g} / \mathrm{mL}$ of the plant extract, the highest activity was observed. In hydrogen peroxide scavenging, when the plant extract concentration increased, the activity of scavenging increased. The highest activity at $3000 \mu \mathrm{g} / \mathrm{mL}$ and the lowest activity at $500 \mu \mathrm{g} / \mathrm{mL}$ were recorded. The SOD test results showed a higher percentage of inhibition of the plant extract at $3000 \mu \mathrm{g} / \mathrm{mL}(79.8 \%)$ and a lower percentage at the dose of $500 \mu \mathrm{g} / \mathrm{mL}$ (21.0\%). Table 1 shows the phytoconstituents of the ethanol extract, while Table 2 summarizes the antioxidant activity of various assays.

Table 1. Phytoconstituents in the ethanol extract of the A. camelorum plant.

\begin{tabular}{ccc}
\hline Serial No & Test & Ethanolic Extract \\
\hline 1 & Flavonoids & +++ \\
\hline 2 & Phenols & +++ \\
\hline 3 & Tannins & +++ \\
\hline 4 & Saponins & +++ \\
\hline 5 & Triterpenoids & - \\
\hline 6 & Steroids & - \\
\hline 7 & Anthocyanins & \\
\hline$+++=$ Highly present, $-=$ absent. & &
\end{tabular}

Table 2. Outcomes of the antioxidant activity of the A. camelorum plant extract using the disparate test.

\begin{tabular}{|c|c|c|c|c|c|c|c|c|c|c|}
\hline \multirow{2}{*}{$\begin{array}{l}\text { Concentration } \\
(\mu \mathrm{g} / \mathrm{mL})\end{array}$} & \multicolumn{5}{|c|}{ Inhibition of the Extract } & \multicolumn{5}{|c|}{ Inhibition of the Standard } \\
\hline & DPPH & $\begin{array}{l}\text { Reducing } \\
\text { Power }\end{array}$ & NO & $\mathrm{H}_{2} \mathrm{O}_{2}$ & SOD & DPPH & $\begin{array}{l}\text { Reducing } \\
\text { Power }\end{array}$ & NO & $\mathrm{H}_{2} \mathrm{O}_{2}$ & SOD \\
\hline 500 & 26.07 & 60.1 & 29 & 26 & 21.0 & 31.26 & 62.4 & 31.7 & 28 & 20.2 \\
\hline 1000 & 46.60 & 71.6 & 39.4 & 36 & 31.68 & 51.47 & 71.7 & 43.3 & 40 & 33.7 \\
\hline 1500 & 61.89 & 87.05 & 51.3 & 51 & 48.18 & 64.53 & 84.8 & 54.6 & 52.6 & 44.08 \\
\hline 2000 & 79.64 & 91.3 & 62 & 68 & 59.3 & 83.49 & 91.6 & 66.8 & 70 & 64.10 \\
\hline 2500 & 88.24 & 96.9 & 71.6 & 94 & 66.2 & 88.97 & 95.8 & 75.5 & 102 & 71.87 \\
\hline 3000 & 96.07 & 108.9 & 75.9 & 128 & 79.86 & 96.93 & 105.8 & 79.8 & 131.6 & 86.03 \\
\hline
\end{tabular}

\subsection{HPLC Analysis}

The HPLC analysis revealed many phytoconstituents in varying concentrations at a $280 \mathrm{~nm}$ wavelength, as shown in (Figure 1). 


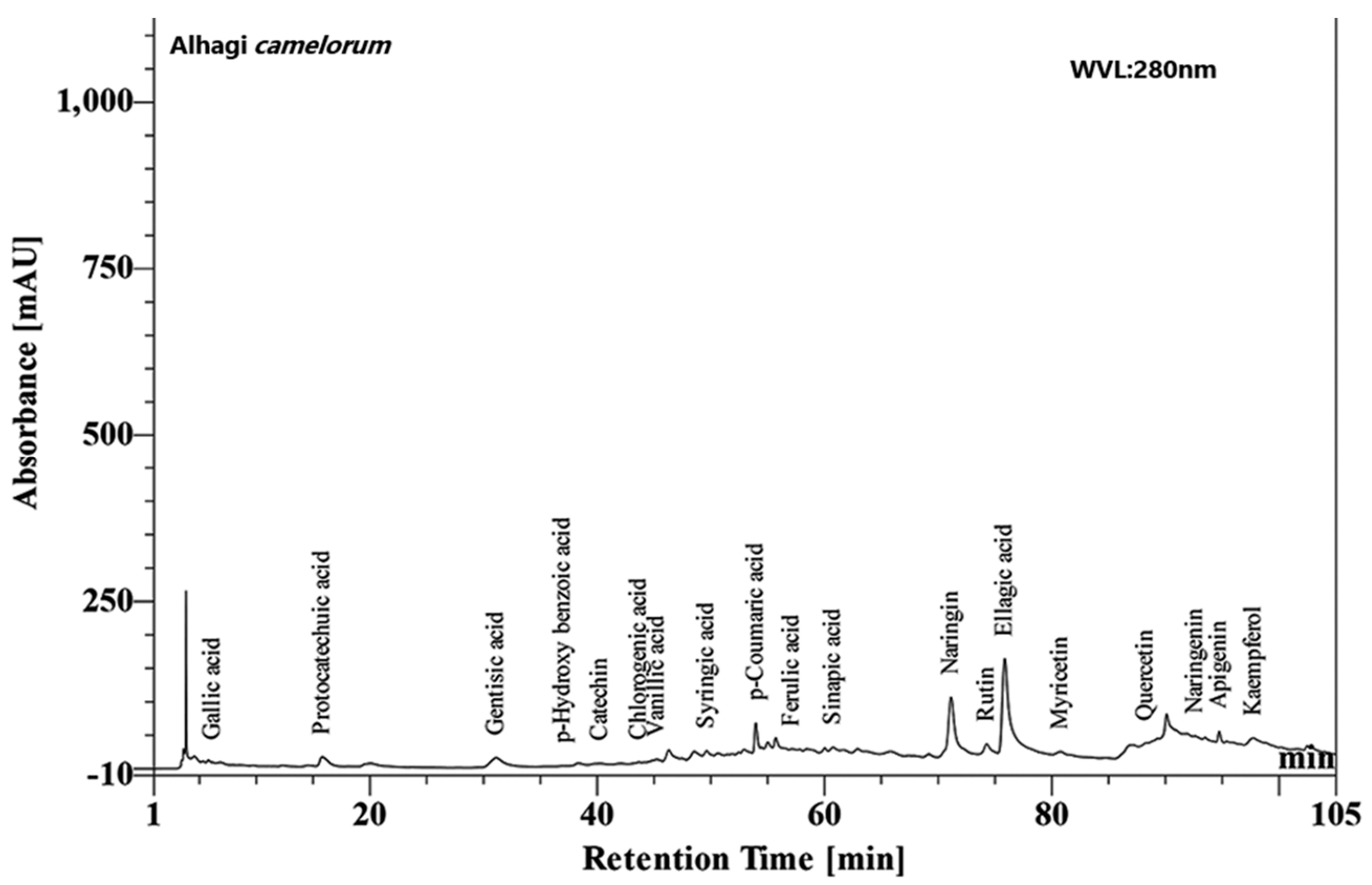

Figure 1. HPLC chromatogram of the hydroalcoholic plant extract of Alhagi camelorum showing gallic acid, rutin, etc.

\subsection{Acute Oral Toxicity Dose Test}

The current study was performed in compliance with OECD. Guideline 423 found that the maximum dose was preserved at $3000 \mathrm{mg} / \mathrm{kg}$. The acute oral toxicity of the extract was evaluated in 24 rats. They were divided into six groups, and each group contained four rats that were fasted for $24 \mathrm{~h}$ and then dosed in the following manner: 500, 1000, 1500, 2000, 2500 , and $3000 \mathrm{mg} / \mathrm{kg}$ body weight. After the dosing, the rats were observed for 14 days for lethargy, jerkiness, and death

\section{Relative Organ Weight}

Table 3 shows the average relative organ weights for rats treated with the maximal dose of the plant extract $(6000 \mathrm{mg} / \mathrm{kg})$. The relative weights of the kidneys, liver, heart, lungs, stomach, and spleen were not considerably different between the control and the treatment group.

Table 3. The impact of the A. camelorum plant extraction the weight of organs of the rats.

\begin{tabular}{ccc}
\hline Treatment & Control Group & Treatment Group \\
\hline Stomach & $0.93 \pm 0.10$ & $0.92 \pm 0.28$ \\
\hline Heart & $0.76 \pm 0.13$ & $0.72 \pm 0.48$ \\
\hline Liver & $5.34 \pm 0.76$ & $6.26 \pm 0.76$ \\
\hline Kidney & $3.4 \pm 0.32$ & $3.5 \pm 0.35$ \\
\hline Spleen & $1.47 \pm 0.35$ & $1.65 \pm 0.39$ \\
\hline Lung & $1.06 \pm 0.49$ & $1.93 \pm 0.29$ \\
\hline
\end{tabular}

Organ/body weight (\%). Mean \pm SEM values $(n=5)$. 
3.4. Effect of the A. camelorum Plant Extract on the Body Weight and Plasma K of Cis-Treated Rats

Nephrotoxicity is caused by a unilateral dose of cisplatin $(5 \mathrm{mg} / \mathrm{kg}$ i.p) that was biochemically shown by increases $(p \leq 0.05)$ in body weight, urine output, urinary sodium, urinary potassium, plasma creatinine, and kidney weight. In contrast, the cisplatin caused a decrease $(p \leq 0.05)$ in plasma Na and K and urinary creatinine. Table 4 shows the body and plasma potassium levels between the control and cisplatin treatment and after the experiment with Ac extracts on days 0, 7, 14, and 21 after dose administration. Compared with the control, there was a decrease in body weight after cisplatin treatment on days 7,14, and 21. Treatment with Ac protected against a loss in body weight. It was observed that the body weight increased up to the 14th day and then started to decrease, and maximum B.W. and plasma potassium were measured after 14th days of observation with both plant extracts. It was also observed that higher dose administration of the extract increased the B.W. and plasma potassium levels of rats compared to a lower dose. However, the decrease in B.W. and plasma potassium indicated the presence of nephrotoxicity.

Table 4. Effect of crude extracts of Ac on B.W \& plasma potassium of cisplatin-treated rats.

\begin{tabular}{|c|c|c|c|c|}
\hline \multirow{2}{*}{$\begin{array}{c}\text { Body Weight (g) } \\
\text { Groups }\end{array}$} & \multicolumn{4}{|c|}{ Observation (Day) } \\
\hline & 0 & 7 & 14 & 21 \\
\hline \multicolumn{5}{|c|}{ A. camelorum (Ac) } \\
\hline Control & $264 \pm 9.7$ & $286 \pm 10.4$ & $348 \pm 10.2$ & $326 \pm 10.7$ \\
\hline Cis & $268 \pm 9.3$ & $206 \pm 10.1\left(^{*}\right)$ & $209 \pm 11\left(^{*}\right)$ & $184 \pm 10.6\left(^{*}\right)$ \\
\hline $\mathrm{Cis}+\mathrm{Ac}^{\mathrm{a}}$ & $287 \pm 10.6$ & $230 \pm 9.3(\&)$ & $267 \pm 10.8(\&)$ & $250 \pm 12(\&)$ \\
\hline $\mathrm{Cis}+\mathrm{Ac}^{\mathrm{b}}$ & $289 \pm 10.8$ & $240 \pm 7.7(\#)$ & $304 \pm 10.6(\#)$ & $289 \pm 10.3(\#)$ \\
\hline \multicolumn{5}{|c|}{ Plasma potassium (mEq/L) } \\
\hline Control & $8.3 \pm 0.58$ & $7.9 \pm 0.69$ & $8.5 \pm 0.58$ & $8.3 \pm 0.48$ \\
\hline Cis & $8.0 \pm 0.32$ & $3.1 \pm 0.44\left(^{*}\right)$ & $4.6 \pm 0.45\left(^{*}\right)$ & $4.6 \pm 0.52\left(^{*}\right)$ \\
\hline $\mathrm{Cis}+\mathrm{Ac}^{\mathrm{a}}$ & $8.0 \pm 0.66$ & $5.5 \pm 0.46(\&)$ & $5.8 \pm 0.48(\&)$ & $5.1 \pm 0.35(\&)$ \\
\hline $\mathrm{Cis}+\mathrm{Ac}^{\mathrm{b}}$ & $8.3 \pm 0.47$ & $6.7 \pm 0.44$ & $6.3 \pm 0.53(\#)$ & $7.2 \pm 0.57(\#)$ \\
\hline
\end{tabular}

Mean \pm SEM $(n=6)$, where Cis is cisplatin (5 mg/kg i.p), Cis $+\mathrm{Ac}^{\mathrm{a}}$ is cisplatin + Alhagi camelorum extract $(400 \mathrm{mg} / \mathrm{kg} / 21$ days $), \mathrm{Cis}+\mathrm{Ac}^{\mathrm{b}}$ is cisplatin + Alhagi camelorum extract $(600 \mathrm{mg} / \mathrm{kg} / 21$ days. The results are considered significant $\left({ }^{*}\right)$ if $p<0.005$. ${ }^{*} p<0.05$ vs. normal control, \& $p<0.05$ vs. cisplatin, and \# $p<0.05$ vs. cisplatin + Alhagi camelorum on corresponding days.

\subsection{Effect of Ac Extracts on Plasma Creatinine and Plasma Sodium of Cis-Treated Rats}

Table 5 presents the effect of Ac extracts on urinary creatinine and plasma sodium of cisplatin-treated rats. Results were observed after $0,7,15$, and 21 days of dose administration. In addition, at $600 \mathrm{mg} / \mathrm{kg}$, co-administration of Cis + AC affected the urinary creatinine and plasma sodium after the 21st day of observation. Overall, cisplatin treatment resulted in increased plasma creatinine and decreased plasma sodium; however, the co-administration of $\mathrm{Cis}+\mathrm{Ac}^{\mathrm{a}}$ and $\mathrm{Cis}+\mathrm{Ac}^{\mathrm{b}}$ significantly reduced the plasma creatinine and increased plasma sodium at rates of 400 and $600 \mathrm{mg} / \mathrm{kg}$. However, it was concluded that $\mathrm{Cis}+\mathrm{Ac}^{\mathrm{a}}$ and $\mathrm{Cis}+\mathrm{Ac}^{\mathrm{b}}$ at $600 \mathrm{mg} / \mathrm{kg}$ showed better results than those observed at $400 \mathrm{mg} / \mathrm{kg}$. 
Table 5. Effect of crude extracts of Ac. on urinary creatinine and plasma Na of cisplatin-treated rats.

\begin{tabular}{|c|c|c|c|c|}
\hline \multirow{2}{*}{$\begin{array}{c}\text { Plasma Sodium }(\mathrm{mEq} / \mathrm{L}) \\
\text { Groups }\end{array}$} & \multicolumn{4}{|c|}{ Observation (Day) } \\
\hline & 0 & 7 & 14 & 21 \\
\hline \multicolumn{5}{|c|}{ Ac } \\
\hline Control & $163 \pm 8.4$ & $201 \pm 8.3$ & $202 \pm 6.7$ & $163 \pm 8.7$ \\
\hline Cis & $172 \pm 7.3$ & $108 \pm 10.4\left(^{*}\right)$ & $135 \pm 8\left(^{*}\right)$ & $127 \pm 9.2\left(^{*}\right)$ \\
\hline $\mathrm{Cis}+\mathrm{Ac}^{\mathrm{a}}$ & $168 \pm 7.2$ & $147 \pm 8.3(\&)$ & $154 \pm 7.6(\&)$ & $148 \pm 9.6(\&)$ \\
\hline $\mathrm{Cis}+\mathrm{Ac} \mathrm{c}^{\mathrm{b}}$ & $173 \pm 6.6$ & $174 \pm 7.9$ (\#) & $179 \pm 7.0$ (\#) & $168 \pm 8.8(\#)$ \\
\hline \multicolumn{5}{|c|}{ Plasma creatinine $(\mathrm{mg} / \mathrm{dL})$} \\
\hline Control & $2.4 \pm 0.47$ & $2.4 \pm 0.47$ & $2.6 \pm 0.41$ & $2.6 \pm 0.56$ \\
\hline Cis & $2.5 \pm 0.40$ & $6.7 \pm 0.30\left(^{*}\right)$ & $7.7 \pm 0.47\left(^{*}\right)$ & $6.0 \pm 0.59\left(^{*}\right)$ \\
\hline $\mathrm{Cis}+\mathrm{Ac}^{\mathrm{a}}$ & $2.6 \pm 0.41$ & $5.7 \pm 0.28(\&)$ & $6.4 \pm 0.58(\&)$ & $6.4 \pm 0.52(\&)$ \\
\hline $\mathrm{Cis}+\mathrm{Ac} \mathrm{c}^{\mathrm{b}}$ & $2.6 \pm 0.56$ & $4.9+0.28(\#)$ & $5.2 \pm 0.30(\#)$ & $5.2 \pm 0.45(\#)$ \\
\hline
\end{tabular}

Mean $\pm \operatorname{SEM}(n=6)$, where Cis is cisplatin $\left(5 \mathrm{mg} / \mathrm{kg}\right.$ i.p), Cis $+\mathrm{Ac}^{\mathrm{a}}$ is cisplatin + Alhagi camelorum extract $\left(400 \mathrm{mg} / \mathrm{kg} / 21\right.$ days), $\mathrm{Cis}+\mathrm{Ac}^{\mathrm{b}}$ is cisplatin + Alhagi camelorum extract $(600 \mathrm{mg} / \mathrm{kg} / 21$ days. The results are considered significant $\left(^{*}\right)$ if $p<0.005$. ${ }^{*} p<0.05$ vs. normal control, $\& p<0.05$ vs. cisplatin, and \# $p<0.05$ vs. cisplatin + Alhagi camelorum on corresponding days.

\subsection{Effect of Ac on Urine Output and Urinary Na in Cis-Treated Rats}

Table 6 shows the effect of the Ac plant extract on urine output and urinary sodium $(\mathrm{Na})$ in Cis-treated rats after 0, 7, 14, and 21 days of dose administration. Overall, cisplatintreated rats showed a reduction in urine output and urinary $\mathrm{Na}$; however, co-administration of $\mathrm{Cis}+\mathrm{Ac}^{\mathrm{a}}$ and $\mathrm{Cis}+\mathrm{Ac}^{\mathrm{b}}$ significantly increased urine output and urinary $\mathrm{Na}$ at a dose of $400 \mathrm{and} 600 \mathrm{mg} / \mathrm{kg}$. However, it was concluded that $\mathrm{Cis}+\mathrm{Ac}^{\mathrm{a}}$ and $\mathrm{Cis}+\mathrm{Ac}^{\mathrm{b}}$ at the $600 \mathrm{mg} / \mathrm{kg}$ rate showed better results than those observed in response to $400 \mathrm{mg} / \mathrm{kg}$.

Table 6. Effect of crude extract of Ac on urine output and urinary Na of cisplatin-treated rats.

\begin{tabular}{ccccc}
\hline Urine Output $(\mathbf{m L})$ & $\mathbf{5}$ Observation (Day) \\
\hline Groups & $\mathbf{0}$ & $\mathbf{7}$ & $\mathbf{1 4}$ & $\mathbf{2 1}$ \\
\hline \multicolumn{5}{c}{ Ac } \\
\hline Control & $9.6 \pm 4.0$ & $9.4 \pm 4.0$ & $9.9 \pm 3.0$ & $9.0 \pm 2.6$ \\
\hline Cis & $9.4 \pm 4.0$ & $38 \pm 4.6\left(^{*}\right)$ & $35 \pm 6.4\left(^{*}\right)$ & $40 \pm 2.9\left(^{*}\right)$ \\
\hline Cis $+\mathrm{Ac}^{\mathrm{a}}$ & $10.4 \pm 3.1$ & $30 \pm 4.0(\&)$ & $29 \pm 10.7(\&)$ & $35 \pm 2.6(\&)$ \\
\hline Cis $+\mathrm{Ac}{ }^{\mathrm{b}}$ & $9.6 \pm 3.0$ & $21 \pm 3.8(\#)$ & $25 \pm 3.9(\#)$ & $29 \pm 1.3(\#)$ \\
\hline Control & Urinary sodium (mEq/L) \\
\hline Cis & $197 \pm 6.4$ & $195 \pm 10.6$ & $201 \pm 9.7$ & $196 \pm 10.8$ \\
\hline Cis $+\mathrm{Ac}^{\mathrm{a}}$ & $194 \pm 6.9$ & $320 \pm 26\left(^{*}\right)$ & $323 \pm 26\left({ }^{*}\right)$ & $372 \pm 21\left(^{*}\right)$ \\
\hline Cis $+\mathrm{Ac}^{\mathrm{b}}$ & $197 \pm 10.4$ & $286 \pm 10.6(\&)$ & $292 \pm 10.0(\&)$ & $310 \pm 26(\&)$ \\
\hline & $188 \pm 8.6$ & $243 \pm 10.7(\#)$ & $260 \pm 11.0(\#)$ & $270 \pm 10(\#)$ \\
\hline
\end{tabular}

Mean \pm SEM $(n=6)$, where Cis is cisplatin (5 mg/kg i.p), Cis + Ac is cisplatin + Alhagi camelorum extract $\left(400 \mathrm{mg} / \mathrm{kg} / 21\right.$ days), $C$ is $+A^{\mathrm{b}}$ is cisplatin + Alhagi camelorum extract $(600 \mathrm{mg} / \mathrm{kg} / 21$ days. The results are considered significant $\left(^{*}\right)$ if $p<0.005$. ${ }^{*} p<0.05$ vs. normal control, $\& p<0.05$ vs. cisplatin, and $\# p<0.05$ vs. cisplatin + Alhagi camelorum on corresponding days.

\subsection{Effect of Ac on Urinary K and Urine Flow Rate in Cis-Treated Rats}

To further analyze the effect of the Ac extract, the level of urinary potassium (K) and urine flow rate were determined in each group of Cis-treated rats. Table 7 shows the results of the effect of the Ac extract on urinary K. The Cis-treated group showed a significant increase in urinary $\mathrm{K}$ from the first day to 21 days of observation compared to the control. 
Results revealed that the 400 and $600 \mathrm{mg} / \mathrm{kg}$ co-administration of Cis + Ac significantly reduced urinary $\mathrm{K}$ after 7 and 21 days of observation compared to the Cis group.

Table 7. Effect of crude extracts of Ac on urinary K and urine flow rate of cisplatin-treated rats.

\begin{tabular}{|c|c|c|c|c|}
\hline \multirow{2}{*}{$\begin{array}{c}\text { Urinary Potassium }(\mathrm{mEq} / 24 \mathrm{~h}) \\
\text { Groups }\end{array}$} & \multicolumn{4}{|c|}{ Observation (Day) } \\
\hline & 0 & 7 & 14 & 21 \\
\hline \multicolumn{5}{|c|}{ Alhagi camelorum (Ac) } \\
\hline Control & $6.3 \pm 0.59$ & $5.5 \pm 0.49$ & $5.8 \pm 0.59$ & $4.0 \pm 0.43$ \\
\hline Cis & $6.8 \pm 0.60$ & $6.8 \pm 0.43\left(^{*}\right)$ & $6.9 \pm 0.53\left(^{*}\right)$ & $7.6 \pm 0.58\left(^{*}\right)$ \\
\hline $\mathrm{Cis}+\mathrm{Ac}^{\mathrm{a}}$ & $6.9 \pm 0.40$ & $6.6 \pm 0.44(\&)$ & $5.9 \pm 0.48(\&)$ & $4.0 \pm 0.40(\&)$ \\
\hline $\mathrm{Cis}+\mathrm{Ac}^{\mathrm{b}}$ & $6.8 \pm 0.76$ & $2.9 \pm 0.44(\#)$ & $4.7 \pm 0.35(\#)$ & $5.3 \pm 0.57(\#)$ \\
\hline \multicolumn{5}{|c|}{ Urine flow rate $(\mu \mathrm{L} / \mathrm{min} / 100 \mathrm{~g}$ of B.W.) } \\
\hline Control & $4.5 \pm 0.78$ & $4.3 \pm 0.67$ & $3.9 \pm 0.52$ & $3.4 \pm 0.65$ \\
\hline Cis & $4.4 \pm 0.65$ & $26 \pm 3.6\left(^{*}\right)$ & $26 \pm 3.4\left(^{*}\right)$ & $28 \pm 3.4\left(^{*}\right)$ \\
\hline $\mathrm{Cis}+\mathrm{Ac}^{\mathrm{a}}$ & $4.5 \pm 0.67$ & $9.8 \pm 0.85(\&)$ & $9.0 \pm 0.72(\&)$ & $8.7 \pm 0.78(\&)$ \\
\hline $\mathrm{Cis}+\mathrm{Ac}^{\mathrm{b}}$ & $3.3 \pm 0.76$ & $7.6 \pm 0.97(\#)$ & $6.2 \pm 0.66(\#)$ & $6.9 \pm 0.59(\#)$ \\
\hline
\end{tabular}

Mean \pm SEM $(n=6)$, where Cis is cisplatin $\left(5 \mathrm{mg} / \mathrm{kg}\right.$ i.p), Cis $+\mathrm{Ac}^{\mathrm{a}}$ is cisplatin + A. camelorum extract $\left(400 \mathrm{mg} / \mathrm{kg} / 21\right.$ days), $\mathrm{Cis}+\mathrm{Ac}^{\mathrm{b}}$ is cisplatin + Alhagi camelorum extract $(600 \mathrm{mg} / \mathrm{kg} / 21$ days. The results are considered significant $\left(^{*}\right)$ if $p<0.005$. ${ }^{*} p<0.05$ vs. normal control, \& $p<0.05$ vs. cisplatin, and $\# p<0.05$ vs. cisplatin + Alhagi camelorum on corresponding days.

\subsection{Effect of Ac on Urinary Creatinine and the Urinary Na/K Ratio in Cis-Treated Rats}

Table 8 shows the nephroprotective effects of Ac on urinary creatinine and the urinary $\mathrm{Na} / \mathrm{K}$ ratio in Cis-treated rats. The cis-treated rats showed a decline in urinary creatinine and an increase in the urinary $\mathrm{Na} / \mathrm{K}$ ratio. It was observed that $\mathrm{Cis}+\mathrm{Ac}$ co-administration at the rate of $600 \mathrm{mg} / \mathrm{kg}$ significantly increased urinary creatinine and decreased the urinary $\mathrm{Na} / \mathrm{K}$ ratio level after 7, 14, and 21 days compared to cisplatin-treated rats; $600 \mathrm{mg} / \mathrm{kg}$ of $\mathrm{Cis}+\mathrm{Ac}$ /significantly increased urinary creatinine and decreased the urinary $\mathrm{Na} / \mathrm{K}$ ratio compared to the Cis group and the $400 \mathrm{mg} / \mathrm{kg}$ concentration.

Table 8. Effect of crude extracts of Ac. on urinary creatinine and the urinary $\mathrm{Na} / \mathrm{K}$ ratio of cisplatintreated rats.

\begin{tabular}{|c|c|c|c|c|}
\hline \multirow{2}{*}{$\frac{\text { Urinary Creatinine }(\mathrm{mg} / \mathrm{dL})}{\text { Groups }}$} & \multicolumn{4}{|c|}{ Observation (Day) } \\
\hline & 0 & 7 & 14 & 21 \\
\hline \multicolumn{5}{|c|}{ Alhagi camelorum (Ac) } \\
\hline Control & $6.8 \pm 0.57$ & $7.4 \pm 0.43$ & $8.8 \pm 0.72$ & $8.2 \pm 0.72$ \\
\hline Cis & $6.8 \pm 0.57$ & $4.2 \pm 0.47\left(^{*}\right)$ & $4.3 \pm 0.44\left(^{*}\right)$ & $3.6 \pm 0.44\left(^{*}\right)$ \\
\hline Cis $+A c^{a}$ & $7.0 \pm 0.59$ & $5.2 \pm 0.45(\&)$ & $5.8 \pm 0.47(\&)$ & $5.5 \pm 0.46(\&)$ \\
\hline $\mathrm{Cis}+\mathrm{Ac} \mathrm{c}^{\mathrm{b}}$ & $6.7 \pm 0.46$ & $6.3 \pm 0.46(\#)$ & $6.3 \pm 0.56(\#)$ & $7.0 \pm 0.39(\#)$ \\
\hline \multicolumn{5}{|c|}{ Urinary $\mathrm{Na} / \mathrm{K}$ ratio } \\
\hline Control & $5.5 \pm 0.70$ & $4.8 \pm 0.70$ & $5.5 \pm 0.69$ & $6.1 \pm 0.68$ \\
\hline Cis & $7.5 \pm 0.60$ & $38 \pm 3.7\left(^{*}\right)$ & $43 \pm 0.97\left(^{*}\right)$ & $44 \pm 6\left(^{*}\right)$ \\
\hline $\mathrm{Cis}+\mathrm{Ac}^{\mathrm{a}}$ & $8.4 \pm 0.90$ & $26 \pm 3.8(\&)$ & $\begin{array}{c}10.7 \pm 0.95 \\
(\&)\end{array}$ & $24 \pm 3.6(\&)$ \\
\hline $\mathrm{Cis}+\mathrm{Ac} \mathrm{c}^{\mathrm{b}}$ & $6.3 \pm 0.66$ & $8.0 \pm 0.86(\#)$ & $6.0 \pm 0.67(\#)$ & $10 \pm 1.3(\#)$ \\
\hline
\end{tabular}

Mean \pm SEM $(n=6)$, where Cis is cisplatin (5 mg/kg i.p), Cis $+\mathrm{Ac}^{\mathrm{a}}$ is cisplatin + Alhagi camelorum extract $\left(400 \mathrm{mg} / \mathrm{kg} / 21\right.$ days), $\mathrm{Cis}+\mathrm{Ac}^{\mathrm{b}}$ is cisplatin + Alhagi camelorum extract $(600 \mathrm{mg} / \mathrm{kg} / 21$ days. The results are considered significant $\left(^{*}\right)$ if $p<0.005$. ${ }^{*} p<0.05$ vs. normal control, \& $p<0.05$ vs. cisplatin, and \# $p<0.05$ vs. cisplatin + Alhagi camelorum on corresponding days. 


\subsection{Impact of Ac Extracts on Kidney Weight in Cis-Treated Rats}

Table 9 shows the Ac extract nephroprotective results on kidney weight in every group. Compared to normal regulation, the kidney weight of animals regarded as Cis was very high. Co-administration of the extract and Cis at varying concentrations led to a reduction in kidney weight.

Table 9. Effect of crude extracts of Ac on kidney weight in Cis-treated rats.

\begin{tabular}{cc}
\hline Groups & Kidney Weight (g) \\
\hline Control & $0.65 \pm 0.058$ \\
\hline Cis & $2.7 \pm 0.035\left(^{*}\right)$ \\
\hline Cis $+A c^{a}$ & $2.6 \pm 0.0068(\&)$ \\
\hline Cis $+A c^{b}$ & $0.98 \pm 0.0066(\#)$ \\
\hline
\end{tabular}

Statistical analysis was carried out using one-way analysis of variance (ANOVA) in all groups on respective days followed by Bonferroni's posthoc test. The results are considered significant $\left(^{*}\right)$ if $p<0.005 .{ }^{*} p<0.05$ vs. normal control, \& $p<0.05$ vs. cisplatin, and \# $p<0.05$ vs. cisplatin + Alhagi camelorum.

\subsection{Histopathological Effects of Ac Extract in Cis-Treated Rats}

The histopathological effects of AC were examined by H\&E staining for histopathological abnormalities. Results showed that the normal kidney showed uniform tubules and normal glomeruli covered with an epithelial layer and showed no blockage, bleeding or interfacial injury. In the Cis group, distorted histology with atrophied glomerulus and collecting tubules with necrosis were observed. Several degenerative changes were also observed in the Cis group in the form of atrophic lining with tubular and eosinophilic casts in cytoplasmic vacuolization of cells. In addition, glomerular hypertrophy was also noted in Cis-treated rats. However, $\mathrm{Cis}+\mathrm{AC}$ co-administration at the $400 \mathrm{mg} / \mathrm{kg}$ rate showed normal glomeruli with mild histopathological results of damage in tubules. On the other hand, $\mathrm{C}$ is $+\mathrm{AC}$ co-administration at $600 \mathrm{mg} / \mathrm{kg}$ rate significantly reduced the histopathological abnormalities induced by $\mathrm{Cis}$. Minor renal damage was found in the proximal and distal tubules compared to Cis + AC-treated groups as shown in Figure 2.
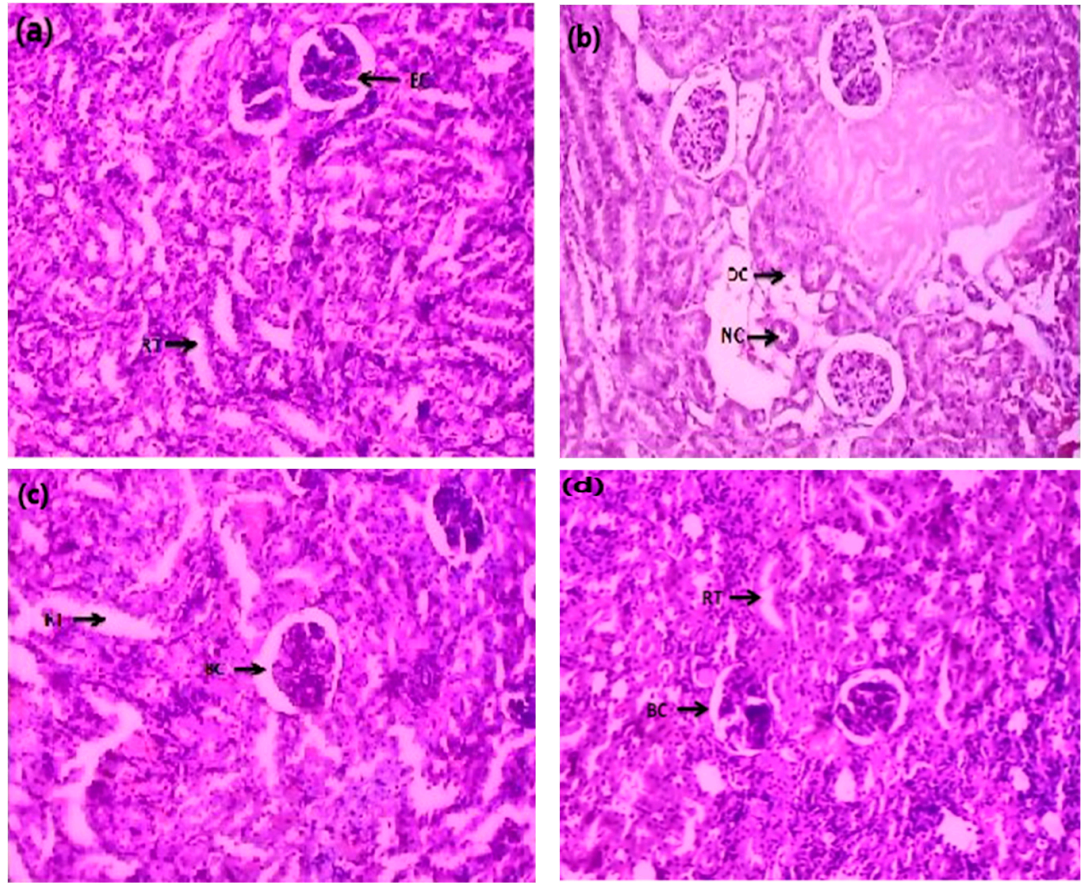

Figure 2. Photomicrograph of kidney sections of rats in the (a) control, (b) Cis, (c) Cis + AC (400 mg/kg), and (d) Cis + AC (600 mg/ kg) groups. BC (Bowman's capsule), RT (renal tubules), DC (distal convoluted tubule), NC (necrosis). 


\section{Discussion}

Cisplatin is a commonly used platinum-containing antineoplastic drug used to treat solid tumors, including those in the breast, lung, head, and neck [41,42]. Despite its multiple advantages in cancer treatment, its uses are limited due to nephrotoxicity [43,44]. With increasing use of Cis, drug-based nephrotoxicity has been increasing day by day and causes almost $26 \%$ of acute kidney injuries (AKI) [45]. The emerging evidence suggested that a single dose of Cis up to $50 \mathrm{mg} / \mathrm{m}^{2}$ induces side effects in the kidney; however, an estimation across $40 \%$ of patients that received Cis higher than this limit suffered from acute or mild renal dysfunction $[46,47]$. It was observed that Cis-induced nephrotoxicity led to renal vasculature that alters renal hemodynamics [48].

Cis is modified due to intracellular hydration to form a reactive metabolite and alters the expression of many water channels and membrane transporters to inhibit the function of mitochondria, ultimately blocking ATP production and leading to nitrosative and oxidative stress [49]. These pharmacological effects lead to the reabsorption and uncoupling of water that precedes the excretion of electrolytes, including magnesium $(\mathrm{Mg})$, sodium $(\mathrm{Na})$, calcium $(\mathrm{Ca})$, potassium $(\mathrm{K})$, and calcium $(\mathrm{Ca})$. Moreover, Cis attacks different organelles and interfaces in DNA replication, altering several biological mechanisms, including necrosis, apoptosis, inflammation, and tubular derangement [40,47]. Mechanisms through which Cis causes nephrotoxicity are complex and involve different biological pathways such as oxidative stress, apoptosis, and inflammation [48]. ROS production is increased by $\mathrm{Cis}$ in mitochondria; NADPH oxidase and the cellular xanthine oxidase system are involved in the pathogenesis of Cis-induced severe kidney failure [17]. The function of various renal antioxidant enzymes, including catalase (CAT), glutathione (GHx), and superoxide dismutase (SOD), is also reduced by Cis [49]. However, based on the side effects of Cis, there is a need to develop a drug to reduce the pathophysiology of Cis. Nowadays, a mixture of different chemicals and natural products are used as potential Cis-neuroreceptors to interfere with the nephrotoxicity of Cis [50].

In the present study, the synergistic effects of Cis with $\mathrm{AC}$ plant extracts were screened at 400 and $600 \mathrm{mg} / \mathrm{kg}$. They showed a significant effect against Cis-induced nephrotoxicity, but the mechanism of action is not fully understood and may involve reducing inflammation, oxidative stress, or apoptosis. The results of the present study revealed that $\mathrm{Cis}$ significantly reduced the bodyweight of rats by increasing the kidney weight. On the other hand, the co-administration of Cis + AC at 400 and $600 \mathrm{mg} / \mathrm{kg}$ significantly $(p<0.001)$ increased the body weight and reduced the kidney weight $(p<0.005)$. The weight loss in the Cis group was strongly related to insufficient nutrition, an increase in metabolic processes, metabolic imbalances, or mental conflict in the Cis-treatment community [51]. In addition, Cis induced tubular necrosis through increased kidney weight in groups treated with Cis due to ischemia or proliferation [49]. In animals treated with Cis + AC $(600 \mathrm{mg} / \mathrm{kg})$, there was a substantial reduction in kidney weight similar to a previous study [52]. Similar results were observed by Singh et al. [53], who revealed that co-administration of Cis $(30 \mathrm{mg} / \mathrm{kg})+$ morin hydrate $(40 \mathrm{mg} / \mathrm{kg})$ significantly reduced the Cis-treated rat kidney weight as compared to the Cis group. Similarly, Sahu et al. $[54,55]$ reported that supplementation of Cis + bai at the $50 \mathrm{mg} / \mathrm{kg}$ rate significantly decreased the relative kidney weight and increased the body weight compared to the Cis group. They also observed a significant reduction in the plasma creatinine level to almost equal to that in the control.

The present study showed that co-administration of Cis + AC extract at 400 and $600 \mathrm{mg} / \mathrm{kg}$ significantly $(p<0.001)$ improved renal function (Tables $1-9) ; 400$ and $600 \mathrm{mg} / \mathrm{kg}$ supplementation of Cis + Ac successfully $(p<0.005)$ increased the urinary sodium $(\mathrm{Na})$, and potassium $(\mathrm{K})$ level up to the control compared to the Cis-group that decreased the plasma $\mathrm{Na}$ and $\mathrm{K}$ levels after a single dose at $5 \mathrm{mg} / \mathrm{kg}$ Cis. In comparison, 400 and $600 \mathrm{mg} / \mathrm{kg}$ co-administration of Cis + AC improved $(p<0.005)$ the plasma creatinine, $\mathrm{Na}$, and $\mathrm{K}$ levels that were reduced after intake of Cis. The weakening of membrane pumps such as Na-K is due to the nephrotoxicity caused by Cis. It leads to a decrease in salt reabsorption and hence increases the urine level [55-57]. In the present 
study, the Cis-group displayed hypernatriuria and hyperkaliuria. Co-administration of Cis + AC (400 and $600 \mathrm{mg} / \mathrm{kg}$ ) allowed sodium and potassium levels to decrease to near normal values relative to the Cis groups (Tables 6 and 7 ).

The results indicated that the AC extract has high nephroprotection. The best outcomes were noted after the 7 th day of the experiment compared to the 14 th and 21st days of observation. Our results are in agreement with the findings of $\mathrm{Ch}$ tourou et al. [58]. They revealed that co-administration of Cis + Naringin100 significantly reduced the serum creatinine level up to $0.47 \pm 0.02 \mathrm{mg} / \mathrm{dL}$ in rats compared to the Cis- group that showed a serum level of $0.97 \pm 0.02 \mathrm{mg} / \mathrm{dL}$ after $5 \mathrm{mg} / \mathrm{kg}$ administration. Similarly, they observed that co-administration of Cis + Naringin $(100 \mathrm{mg} / \mathrm{kg})$ increased the urine creatinine level $(6.27 \pm 0.92 \mathrm{mg} / \mathrm{dL})$ compared to the Cis group $(4.05 \pm 0.12 \mathrm{mg} / \mathrm{dL})$. Fatima et al. [59] demonstrated that co-administration of Cis + A20 (EGCG + CoQ10) reduced the serum creatinine level $(1.36 \pm 0.30 \mathrm{mg} / \mathrm{dL})$ compared to the Cis group $(3.13 \pm 0.25 \mathrm{mg} / \mathrm{dL})$, with urine $\mathrm{Na}, \mathrm{K}, \mathrm{Ca}^{2+}$, and $\mathrm{Mg}^{2+}$ levels of $110 \pm 2.56,28 \pm 3.01,4.83 \pm 0.05$, and $27.4 \pm 2.2 \mu \mathrm{mol} / 24 \mathrm{~h}$, respectively.

Moreover, the histopathological analysis was performed to confirm the effect of both doses of AC on renal function. The results showed that after Cis ( $5 \mathrm{mg} / \mathrm{kg}$ ) administration, the kidney exhibited glomerular hypertrophy, cytoplasmic vacuolization of cells, and atrophic lining with tubular and eosinophilic casts. However, after administration of Cis + AC at the rate of 400 and $600 \mathrm{mg} / \mathrm{kg}$, a significant improvement was observed, indicating that $\mathrm{C}$ is $+\mathrm{AC}$ effectively reduced the renal abnormalities associated with a single injection of Cis.

\section{Conclusions}

Based on our findings, it can be concluded that Alhagi camelorum seems to be safe and have high medicinal value. The ethanol extract showed the presence of flavonoids, phenols, tannins, and saponins and significantly high antioxidant activity. The treated rats did not show any anatomical, physiological or histopathological changes compared to the control. Kidney tissues appeared normal after the maximum dose of the extract with a possible alteration of distal tubules, proximal tubules, and glomerulus in the kidney tissue. The results of reversing Cis-induced nephrotoxicity suggest high potential for the extract for renal damage treatment, and most of the parameters retained to normal values after the administration of AC for only three weeks. The A. camelorum ethanol extract has great potential as an antioxidant and nephrotoxic therapeutic agent. Further studies are required to explore the exact molecular mechanism responsible for its nephroprotective effect, and LC-MS/MS spectrum analysis is recommended for further characterization.

Author Contributions: Original draft, Supervision, Experimentation: M.O.I., M.M.A., I.A.K. Writing-original draft, Software, Editing. M.O.I., S.A. (Shafia Arshad), U.J., S.A. (Shumaila Andleeb), R.R., S.H.M., Z.M., M.M., A.M.; Formal analysis, Editing, \& Investigation. All authors have read and agreed to the published version of the manuscript.

Funding: This is part of a Ph.D. thesis of the first author and received no funding from any funding agency.

Institutional Review Board Statement: The Ethical Board of Muhammad Institute of Medical and Allied Health Sciences approved the study.

Informed Consent Statement: Not applicable.

Acknowledgments: We extend our gratitude to the laboratory staff and staff of the animal house of the Muhammad Institute of Medical and Allied Sciences, Multan, Pakistan, for their cooperation throughout the study. We are grateful to Shifa Clinical laboratory, Multan, for the research facilities.

Conflicts of Interest: The authors declare no conflict of interest. 


$\begin{array}{ll}\text { Abbreviations } \\ \text { DPPH } & \text { 2,2-Diphenyl-1-picrylhydrazyl } \\ \text { SOD } & \text { superoxide dismutase } \\ \mathrm{NO} & \text { Nitric oxide } \\ \mathrm{H}_{2} \mathrm{O}_{2} & \text { Hydrogen peroxide } \\ \mathrm{Ac} & \text { Alhagi camelorum } \\ \mathrm{CAT} & \text { catalase } \\ \mathrm{SOD} & \text { Superoxide dismutase } \\ \mathrm{GHx} & \text { Glutathione } \\ \text { EGCG } & \text { epigallocatechin gallate } \\ \mathrm{CoQ} 10 & \text { Coenzyme Q10 } \\ \text { Bai } & \text { Baicalein }\end{array}$

\section{References}

1. Yadav, N.; Sharma, S.; Sharma, S.; Sharma, K. Critical Analysis of protective role of plants against gentamicin induced nephrotoxicity. Indian J. Environ. Sci. 2017, 21, 1-34.

2. Saylor, C.; Tamayo-Ortiz, M.; Pantic, I.; Amarasiriwardena, C.; McRae, N.; Estrada-Gutierrez, G.; Parra-Hernandez, S.; Tolentino, M.C.; Baccarelli, A.A.; Fadrowski, J.J. Prenatal blood lead levels and reduced preadolescent glomerular filtration rate: Modification by body mass index. Environ. Int. 2021, 154, 106414. [CrossRef] [PubMed]

3. Müller, T.; Dewitz, C.; Schmitz, J.; Schröder, A.S.; Bräsen, J.H.; Stockwell, B.R.; Murphy, J.M.; Kunzendorf, U.; Krautwald, S. Necroptosis and ferroptosis are alternative cell death pathways that operate in acute kidney failure. Cell. Mol. Life Sci. 2017, 74, 3631-3645. [CrossRef] [PubMed]

4. Shah, S.; Leonard, A.C.; Harrison, K.; Meganathan, K.; Christianson, A.L.; Thakar, C.V. Mortality and recovery associated with kidney failure due to acute kidney injury. Clin. J. Am. Soc. Nephrol. 2020, 15, 995-1006. [CrossRef]

5. Shi, M.; McMillan, K.L.; Wu, J.; Gillings, N.; Flores, B.; Moe, O.W.; Hu, M.C. Cisplatin nephrotoxicity as a model of chronic kidney disease. Lab. Investig. 2018, 98, 1105-1121. [CrossRef] [PubMed]

6. Iqbal, M.O.; Sial, A.S.; Akhtar, I.; Naeem, M.; Hazafa, A.; Ansari, R.A.; Rizvi, S.A. The nephroprotective effects of Daucus carota and Eclipta prostrata against cisplatin-induced nephrotoxicity in rats. Bioengineered 2021, 12, 12702-12721. [CrossRef] [PubMed]

7. Guo, H.; Deng, N.; Dou, L.; Ding, H.; Criswell, T.; Atala, A.; Furdui, C.M.; Zhang, Y. 3-D Human Renal Tubular Organoids Generated from Urine-Derived Stem Cells for Nephrotoxicity Screening. ACS Biomater. Sci. Eng. 2020, 6, 6701-6709. [CrossRef]

8. Manohar, S.; Leung, N. Cisplatin nephrotoxicity: A review of the literature. J. Nephrol. 2018, 31, 15-25. [CrossRef] [PubMed]

9. Casanova, A.G.; Hernández-Sánchez, M.T.; López-Hernández, F.J.; Martínez-Salgado, C.; Prieto, M.; Vicente-Vicente, L.; Morales, A.I. Systematic review and meta-analysis of the efficacy of clinically tested protectants of cisplatin nephrotoxicity. Eur. J. Clin. Pharmacol. 2020, 76, 23-33. [CrossRef]

10. Miller, R.P.; Tadagavadi, R.K.; Ramesh, G.; Reeves, W.B. Mechanisms of cisplatin nephrotoxicity. Toxins 2010, 2, 2490-2518 [CrossRef]

11. Yang, H.; Tang, J.; Guo, D.; Zhao, Q.; Wen, J.; Zhang, Y.; Obianom, O.N.; Zhou, S.; Zhang, W.; Shu, Y. Cadmium exposure enhances organic cation transporter 2 trafficking to the kidney membrane and exacerbates cisplatin nephrotoxicity. Kidney Int. 2020, 97, 765-777. [CrossRef] [PubMed]

12. Phung, H.M.; Lee, S.; Hwang, J.H.; Kang, K.S. Preventive Effect of Muscone against Cisplatin Nephrotoxicity in LLC-PK1 Cells. Biomolecules 2020, 10, 1444. [CrossRef] [PubMed]

13. Wang, Y.; Tang, C.; Cai, J.; Chen, G.; Zhang, D.; Zhang, Z.; Dong, Z. PINK1/Parkin-mediated mitophagy is activated in cisplatin nephrotoxicity to protect against kidney injury. Cell Death Dis. 2018, 9, 1-14. [CrossRef] [PubMed]

14. Farooqui, Z.; Ahmed, F.; Rizwan, S.; Shahid, F.; Khan, A.A.; Khan, F. Protective effect of Nigella sativa oil on cisplatin induced nephrotoxicity and oxidative damage in rat kidney. Biomed. Pharmacother. 2017, 85, 7-15. [CrossRef] [PubMed]

15. Qi, Z.; Li, W.; Tan, J.; Wang, C.; Lin, H.; Zhou, B.; Liu, J.; Li, P. Effect of ginsenoside Rh2 on renal apoptosis in cisplatin-induced nephrotoxicity in vivo. Phytomedicine 2019, 61, 152862. [CrossRef]

16. Abdel-Daim, M.M.; Aleya, L.; El-Bialy, B.E.; Abushouk, A.I.; Alkahtani, S.; Alarifi, S.; Alkahtane, A.A.; AlBasher, G.; Ali, D.; Almeer, R.S. The ameliorative effects of ceftriaxone and vitamin E against cisplatin-induced nephrotoxicity. Environ. Sci. Pollut. Res. 2019, 26, 15248-15254. [CrossRef]

17. Fang, C.-Y.; Lou, D.-Y.; Zhou, L.-Q.; Wang, J.-C.; Yang, B.; He, Q.-J.; Wang, J.-J.; Weng, Q.-J. Natural products: Potential treatments for cisplatin-induced nephrotoxicity. Acta Pharmacol. Sin. 2021, 42, 1951-1969. [CrossRef]

18. Gutierrez, R.M.; Gomez, Y.G.; Ramirez, E.B. Nephroprotective activity of Prosthechea michuacana against cisplatin-induced acute renal failure in rats. J. Med. Food 2010, 13, 911-916. [CrossRef]

19. Cayir, K.; Karadeniz, A.; Simsek, N.; Yildirim, S.; Karakus, E.; Kara, A.; Akkoyun, H.T.; Sengul, E. Pomegranate seed extract attenuates chemotherapy-induced acute nephrotoxicity and hepatotoxicity in rats. J. Med. Food 2011, 14, 1254-1262. [CrossRef]

20. Sultana, S.; Verma, K.; Khan, R. Nephroprotective efficacy of chrysin against cisplatin-induced toxicity via attenuation of oxidative stress. J. Pharm. Pharmacol. 2012, 64, 872-881. [CrossRef] 
21. Xiang, X.; Guo, C.; Tang, C.; Cai, J.; Dong, Z. Epigenetic regulation in kidney toxicity: Insights from cisplatin nephrotoxicity. Semin. Nephrol. 2019, 39, 152-158. [CrossRef] [PubMed]

22. Chakraborty, S.; Majumdar, S. Natural products for the treatment of pain: Chemistry and pharmacology of Salvinorin A, Mitragynine, and Collybolide. Biochemistry 2020, 60, 1381-1400. [CrossRef]

23. Hazafa, A.; Rehman, K.-U.; Jahan, N.; Jabeen, Z. The role of polyphenol (flavonoids) compounds in the treatment of cancer cells. Nutr. Cancer 2020, 72, 386-397. [CrossRef] [PubMed]

24. Khan, F.M. Ethno-veterinary medicinal usage of flora of Greater Cholistan desert (Pakistan). Pak. Vet. J. 2009, 29, 75-78.

25. Marwat, S.K. Ethnophytomedicines for treatment of various diseases in DI Khan district. Sarhad J. Agric. 2008, $24,305-315$.

26. Ballabh, B.; Chaurasia, O.P. Traditional medicinal plants of cold desert Ladakh-Used in treatment of cold, cough and fever. J. Ethnopharmacol. 2007, 112, 341-349. [CrossRef] [PubMed]

27. Donkor, S.; Larbie, C.; Komlaga, G.; Emikpe, B.O. Evaluation of the Acute Hepatoprotective Potential of Hydroethanolic Extract of Duranta erecta L. Parts. J. Toxicol. 2020, 2020, 8815719. [CrossRef] [PubMed]

28. Irshad, M.; Subhani, M.A.; Ali, S.; Hussain, A. Biological importance of essential oils. In Essential Oils-Oils of Nature; IntechOpen: London, UK, 2020.

29. Singh, B.; Koley, T.; Maurya, A.; Singh, P.; Singh, B. Phytochemical and antioxidative potential of orange, red, yellow, rainbow and black coloured tropical carrots (Daucus carota subsp. sativus Schubl. \& Martens). Physiol. Mol. Biol. Plants 2018, $24,899-907$.

30. National Institute of Health. Guide for the Care and Use of Laboratory Animals; No. 85-23; NIH Publication: Bethesda, MD, USA, 1985.

31. Chung, I.-M.; Rajakumar, G.; Lee, J.-H.; Kim, S.-H.; Thiruvengadam, M. Ethnopharmacological uses, phytochemistry, biological activities, and biotechnological applications of Eclipta prostrata. Appl. Microbiol. Biotechnol. 2017, 101, 5247-5257. [CrossRef]

32. Wang, R.; Hassan, W.; Jabeen, Q.; Ahmed, H.; Iqbal, O. Citrus aurantium ameliorates cisplatin-induced nephrotoxicity. BioMed Res. Int. 2019, 2019, 3960908. [CrossRef]

33. Iqbal, M.O.; Yahya, E.B.; Andleeb, S.; Ahmed, M.M.; Javaid, M.U.; Shakeel, W.; Iqbal, I. In vivo assessment of reversing CisplatinInduced nephrotoxicity using Jatropha mollissima crude extract and its potential cytotoxicity. Saudi J. Biol. Sci. 2021, 28, 7373-7378. [CrossRef] [PubMed]

34. Evans, W.C. Trease and Evans Pharmacognosy; Saunders: Edinburgh, UK; New York, NY, USA, 2009.

35. Seal, T.; Pillai, B.; Chaudhuri, K. Effect of solvent extraction system on the antioxidant activity of some selected wild leafy vegetables of Meghalaya state in India. Int. J. Pharm. Sci. Res. 2013, 4, 1046-1051.

36. Kpemissi, M.; Metowogo, K.; Melila, M.; Veerapur, V.P.; Negru, M.; Taulescu, M.; Potârniche, A.-V.; Suhas, D.S.; Puneeth, T.A.; Vijayakumar, S. Acute and subchronic oral toxicity assessments of Combretum micranthum (Combretaceae) in Wistar rats. Toxicol. Rep. 2020, 7, 162-168. [CrossRef] [PubMed]

37. Mensor, L.L.; Menezes, F.S.; Leitão, G.G.; Reis, A.S.; Santos, T.C.D.; Coube, C.S.; Leitão, S.G. Screening of Brazilian plant extracts for antioxidant activity by the use of DPPH free radical method. Phytother. Res. 2001, 15, 127-130. [CrossRef] [PubMed]

38. Gowda, S.; Desai, P.B.; Kulkarni, S.S.; Hull, V.V.; Math, A.A.; Vernekar, S.N. Markers of renal function tests. N. Am. J. Med. Sci. 2010, 2, 170. [PubMed]

39. Jen, J.F.; Hsiao, S.L.; Liu, K.H. Simultaneous determination of uric acid and creatinine in urine by an eco-friendly solvent-free high performance liquid chromatographic method. Talanta 2002, 58, 711-717. [CrossRef]

40. Seeling, H.P.; Wust, H. Colorimetric method for determination of creatinine. Arztl. Lab. 1969, 15, 34.

41. Hu, S.; Wang, J.; Wang, J.; Li, S.; Jiang, W.; Liu, Y. Renoprotective effect of fucoidan from Acaudina molpadioides in streptozotocin/high fat diet-induced type 2 diabetic mice. J. Funct. Foods 2017, 31, 123-130. [CrossRef]

42. Izuwa, Y.; Kusaba, J.-I.; Horiuchi, M.; Aiba, T.; Kawasaki, H.; Kurosaki, Y. Comparative study of increased plasma quinidine concentration in rats with glycerol-and cisplatin-induced acute renal failure. Drug Metab. Pharmacokinet. 2009, $24,451-457$. [CrossRef] [PubMed]

43. Kpemissi, M.; Eklu-Gadegbeku, K.; Veerapur, V.P.; Negru, M.; Taulescu, M.; Chandramohan, V.; Hiriyan, J.; Banakar, S.M.; Thimmaiah, N.; Suhas, D.S. Nephroprotective activity of Combretum micranthum G. Don in cisplatin induced nephrotoxicity in rats: In-vitro, in-vivo and in-silico experiments. Biomed. Pharmacother. 2019, 116, 108961. [CrossRef]

44. Ma, Z.-N.; Li, Y.-Z.; Li, W.; Yan, X.-T.; Yang, G.; Zhang, J.; Zhao, L.-C.; Yang, L.-M. Nephroprotective effects of saponins from leaves of Panax quinquefolius against cisplatin-induced acute kidney injury. Int. J. Mol. Sci. 2017, 18, 1407. [CrossRef] [PubMed]

45. Liu, M.; Jia, Z.; Sun, Y.; Zhang, A.; Yang, T. A H2S Donor GYY4137 Exacerbates Cisplatin-Induced Nephrotoxicity in Mice. Mediat. Inflamm. 2016, 2016, 8145785. [CrossRef] [PubMed]

46. Liu, L.; Jiang, L.; Yuan, W.; Liu, Z.; Liu, D.; Wei, P.; Zhang, X.; Yi, T. Dual-Modality Detection of Early-Stage Drug-Induced Acute Kidney Injury by an Activatable Probe. ACS Sens. 2020, 5, 2457-2466. [CrossRef]

47. Tsang, R.Y.; Al-Fayea, T.; Au, H.-J. Cisplatin overdose. Drug Saf. 2009, 32, 1109-1122. [CrossRef] [PubMed]

48. Mehta, R.L.; Awdishu, L.; Davenport, A.; Murray, P.T.; Macedo, E.; Cerda, J.; Chakaravarthi, R.; Holden, A.L.; Goldstein, S.L. Phenotype standardization for drug-induced kidney disease. Kidney Int. 2015, 88, 226-234. [CrossRef]

49. Ashrafi, F.; Ebrahimi, Z.; Nematbakhsh, M. Effect of short hydration on cisplatin-induced nephrotoxicity in cancer patients: A retrospective study. Int. J. Hematol. Oncol. Stem Cell Res. 2017, 11, 262.

50. Sánchez-González, P.D.; López-Hernández, F.J.; López-Novoa, J.M.; Morales, A.I. An integrative view of the pathophysiological events leading to cisplatin nephrotoxicity. Crit. Rev. Toxicol. 2011, 41, 803-821. [CrossRef] 
51. Sancho-Martínez, S.M.; Prieto-García, L.; Prieto, M.; Lopez-Novoa, J.M.; López-Hernández, F.J. Subcellular targets of cisplatin cytotoxicity: An integrated view. Pharmacol. Ther. 2012, 136, 35-55. [CrossRef]

52. Sancho-Martinez, S.M.; Prieto-García, L.; Prieto, M.; Fuentes-Calvo, I.; Lopez-Novoa, J.M.; Morales, A.I.; Martínez-Salgado, C.; Lopez-Hernandez, F.J. N-acetylcysteine transforms necrosis into apoptosis and affords tailored protection from cisplatin cytotoxicity. Toxicol. Appl. Pharmacol. 2018, 349, 83-93. [CrossRef]

53. Singh, M.P.; Chauhan, A.K.; Kang, S.C. Morin hydrate ameliorates cisplatin-induced E.R. stress, inflammation and autophagy in HEK-293 cells and mice kidney via PARP-1 regulation. Int. Immunopharmacol. 2018, 56, 156-167. [CrossRef]

54. Sahu, B.D.; Kumar, J.M.; Sistla, R. Baicalein, a bioflavonoid, prevents cisplatin-induced acute kidney injury by up-regulating antioxidant defenses and down-regulating the MAPKs and NF-kB pathways. PLoS ONE 2015, 10, e0134139. [CrossRef] [PubMed]

55. Yao, X.; Panichpisal, K.; Kurtzman, N.; Nugent, K. Cisplatin nephrotoxicity: A review. Am. J. Med. Sci. 2007, 334, 115-124. [CrossRef] [PubMed]

56. Pabla, N.; Dong, Z. Cisplatin nephrotoxicity: Mechanisms and renoprotective strategies. Kidney Int. 2008, 73, 994-1007. [CrossRef] [PubMed]

57. Chtourou, Y.; Aouey, B.; Aroui, S.; Kebieche, M.; Fetoui, H. Anti-apoptotic and anti-inflammatory effects of naringin on cisplatin-induced renal injury in the rat. Chem.-Biol. Interact. 2016, 243, 1-9. [CrossRef] [PubMed]

58. Landau, S.I.; Guo, X.; Velazquez, H.; Torres, R.; Olson, E.; Garcia-Milian, R.; Moeckel, G.W.; Desir, G.V.; Safirstein, R. Regulated necrosis and failed repair in cisplatin-induced chronic kidney disease. Kidney Int. 2019, 95, 797-814. [CrossRef] [PubMed]

59. Fatima, S.; Al-Mohaimeed, N.; Al-Shaikh, Y.; Tyagi, P.; Banu, N.; Hasan, S.; Arjumand, S. Combined treatment of epigallocatechin gallate and Coenzyme Q10 attenuates cisplatin-induced nephrotoxicity via suppression of oxidative/nitrosative stress, inflammation and cellular damage. Food Chem. Toxicol. 2016, 94, 213-220. [CrossRef] [PubMed] 